\title{
Evaluation of the intensity and discomfort of perioperative thirst
}

\author{
Avaliação da intensidade e desconforto da sede perioperatória \\ Evaluación de la intensidad e incomodidad de la sed perioperatoria
}

\author{
Isadora Pierotti ${ }^{1}$ \\ Isabela Fernanda Larios Fracarolli ${ }^{1}$ \\ Lígia Fahl Fonseca ${ }^{1}$ \\ Patrícia Aroni $^{1}$
}

1. Universidade Estadual de Londrina.

Londrina, PR, Brasil.
Corresponding author:

Isadora Pierotti.

E-mail: isa_pierotti@hotmail.com

Submitted on $12 / 11 / 2017$.

Accepted on $03 / 21 / 2018$.

DOI: 10.1590/2177-9465-EAN-2017-0375

\section{Abstract}

Objective: To evaluate the intensity and discomfort of perioperative thirst and related factors during anesthesia recovery. Method: This is a quantitative, cross-sectional, descriptive study. Results: Of the 203 participants, $182(89.6 \%)$ reported they were thirsty. The mean intensity of thirst was 6.9 measured using a verbal numerical scale of 0 to 10 and discomfort was 7.3 on a scale of 0 to 14 . All attributes evaluated by the scale were cited including dry mouth and desire to drink water (87.3\%), dry lips (79.1\%), thick tongue feeling $(43.4 \%)$, thick saliva $(56.5 \%)$, dry throat $(75.2 \%)$ and bad taste in the mouth $(63.1 \%)$. There was a positive correlation between the intensity of thirst and discomfort assessed by the scale (Spearman coefficient: $0.474 ; p$-value: $<0.05$ ). No correlation was found between age, length of fasting and use of opioids with the intensity of thirst and discomfort. Conclusion and implication in the clinical practice: Discomfort arising from the attributes of thirst is evidenced as the intensity of thirst increases.

Keywords: Thirst; Nursing; Perioperative Care; Postoperative Period.

\section{Resumo}

Objetivo: Avaliar a intensidade e o desconforto da sede perioperatória e fatores associados durante a recuperação anestésica. Método: Estudo quantitativo, transversal, descritivo. Resultados: Dos 203 participantes, $182(89,6 \%)$ sentiram sede. A intensidade média da sede foi 6,9, avaliada em escala numérica analógica e a de seus desconfortos, 7,3, em escala de 0 a 14 . Todos os atributos avaliados pela escala foram citados: boca seca e vontade de beber água (87,3\%), lábios ressecados $(79,1 \%)$, língua grossa $(43,4 \%)$, saliva grossa $(56,5 \%)$, garganta seca $(75,2 \%)$, gosto ruim na boca $(63,1 \%)$. Houve correlação positiva entre intensidade da sede e pontuação dos desconfortos avaliados pela escala (Spearman $=0,474 / p=<0,05$ ). Não houve correlação entre idade, tempo de jejum e utilização de opioides com intensidade de sede e seus desconfortos. Conclusão e implicação para a prática: Desconfortos advindos dos atributos da sede são evidenciados à medida que a intensidade da sede aumenta.

Palavras-chave: Sede; Enfermagem; Assistência Perioperatória; Período Pós-Operatório.

\section{Resumen}

Objetivo: Evaluar intensidad e incomodidad de la sed perioperatoria y los factores asociados durante la recuperación anestésica Método: Estudio cuantitativo, transversal, descriptivo. Resultados: De los 203 participantes, 182 (89,6\%) sintieron sed. La intensidad media de la sed fue 6,9, evaluada en escala numérica analógica; sus incomodidades, 7,3, en escala de 0 a 14 . Todos los atributos evaluados fueron citados: boca seca y ganas de beber agua $(87,3 \%)$, labios resecados $(79,1 \%)$, lengua gruesa $(43,4 \%)$, saliva gruesa $(56,5 \%)$, garganta seca $(75,2 \%)$, gusto malo en la boca $(63,1 \%)$. Se observó correlación positiva entre intensidad de la sed y puntuación de las molestias evaluadas por la escala (Spearman $=0,474 / p=<0,05$ ). No hubo correlación entre edad, tiempo de ayuno y utilización de opioides con intensidad de sed y sus incomodidades. Conclusión e implicación para la práctica: Incomodidad proveniente de los atributos de la sed se evidencia a medida que la intensidad de la sed aumenta.

Palabras clave: Sed; Enfermeria; Atención Perioperatoria; Periodo Posoperatorio 


\section{INTRODUCTION}

Described as a multifactorial symptom, thirst is very prevalent in the immediate postoperative period (IPO), affecting $75 \%$ of adult patients. ${ }^{1}$ It is related to sensations that cause intense discomfort such as dry mouth, thick saliva and body fatigue. ${ }^{2-5}$ The presence of this symptom involves motivational responses such as the pleasantness of drinking water during meals and emotional states, such as anxiety that can cause a reduction in saliva production. These factors drive human beings to search for fluids and are influenced by conditions of the environment, health and disease. Perception of thirst involves both physiological factors controlled by a complex regulatory mechanism and personal habits. ${ }^{4,5}$

In the clinical practice and in research, thirst is usually measured using self-assessment scales. High correlations have been found between the intensity of thirst with its attributes ${ }^{3}$ and with changes in osmolarity and the release of the antidiuretic hormone $\mathrm{ADH} .{ }^{6}$ This demonstrates that subjective assessment of the intensity of thirst may be indicative of the physiological changes caused by it.

The intensity of thirst can be assessed using analogous scales such as the Visual Analog Scale (VAS), Verbal Numerical Scale (VNS), Verbal Descriptor Scale (VDS) and Faces Pain Scale (FPS). ${ }^{7-9}$

Thirst is considered one of the greatest stressors for patients during the IPO. ${ }^{10}$ In an attempt to describe the amount of discomfort it causes in this period, patients use figurative speech, comparing themselves to 'a camel crossing the desert' or verbalizing that they have 'the sensation of having ingested a tube of glue.' In addition, the sensations described by the surgical patient when faced with no prospect of quenching their thirst due to the mandatory fasting in the surgical period are of despair even including thoughts of death. ${ }^{11}$ Paradoxically for the nursing and anesthesiology team, the thirst of the surgical patient is still a symptom of little importance. ${ }^{12,13}$

Of the various physiological needs, one of the most primary of the human being and essential for comfort is that of drinking water. On the other hand, the term comfort is related to a state of equilibrium provided by the satisfaction of some basic human need, such as the absence or control of pain, suffering or worry. The presence of these factors may be associated with the meaning of the word discomfort. ${ }^{14}$ The surgical patient, when thirsty, is in an imbalanced state that is manifested by subjective signs and sensations and by attributes such as dry mouth, dry throat and the desire to drink water, among others. ${ }^{2,3,8}$

A scale called the Perioperative Headache Discomfort Scale $(\mathrm{PHDS})^{8}$ was developed and validated to evaluate attributes related to thirst in the perioperative period. This scale presented high validity and reliability rates in respect to the surgical patient. The content validity index of this scale was 0.98 and the inter-rater reliability index was 1 . The instrument is reliable, with a weighted kappa coefficient of 1 for items and Cronbach's alpha of $0.91 .^{8}$

The PHDS evalutes the attributes: dry mouth, dry lips, thick tongue feeling, thick saliva, dry throat, bad taste in the mouth and the desire to drink water on a three-point Likert scale, which is easy to use even when the patient is recovering from anesthesia in the perioperative period. ${ }^{8}$ Studies of thirst usually focus on the intensity but fail to identify and analyze the degree of discomfort it causes.

Of the factors considered predictors of thirst in the perioperative period are the use of anesthetic drugs especially opioids and anticholinergic agents, and the preoperative fasting. ${ }^{15,16}$ There is a scarcity of data on the associations between these predictors and the discomfort caused by thirst.

The intensity of thirst has a positive correlation with osmotic and plasma changes that trigger the release of the antidiuretic hormone $\mathrm{ADH}$, considered one of the main hormones that regulates thirst. ${ }^{6}$ Thus, although the assessment of the intensity using the VNS and VAS is subjective, it reflects a state of blood changes that control the genesis and satiation of thirst. Measuring it subjectively, therefore, is a widely used practical method in laboratory and clinical studies to evaluate human thirst. $^{3}$

Hence, because thirst is a multifactorial symptom, it cannot be evaluated solely by its intensity. There is a gap in the studies that investigated the relationship between the intensity of thirst and the discomfort it causes and associated factors in the surgical patient. The current study may increase our understanding about this complex symptom by identifying which attributes of thirst most bother this group of patients.

Thus, this study aims to answer the following question: Is there a relationship between the intensity of thirst and the discomfort it causes with factors associated with this symptom in the IPO during anesthesia recovery?

\section{METHOD}

This is a quantitative, cross-sectional, descriptive study. The study population comprised patients who were submitted to surgery in the study institution. The sample population of 203 participants was non-probabilistic. The minimum sample size was not calculated however a fixed time of four months was established as a condition for data collection.

The inclusion criteria were over 18-year-old patients of both sexes submitted to elective, urgent and emergency surgeries, who spent the IPO in the anesthesia recovery room (ARR), who 
were awake and aware of time and place, and who reported thirst either spontaneously or when questioned. Adult and elderly patients participated in the study. However, few elderly patients participated as most are transferred directly from the operating room to the Intensive Care Unit (ICU) instead of the ARR where the data collection took place. The exclusion criterion was pain reported at the time of data collection, as this symptom can influence the patient's own perception of their thirst.

The study was carried out in the ARR of a tertiary university hospital in the state of Paraná from February to May 2016. This institution, a public hospital with 316 beds, is a regional referral center for burns, bone marrow transplantation, high-risk pregnancies and trauma. It has a surgical center with seven operating rooms, one of which is reserved for urgent/emergency surgeries and a six bed ARR. The surgical center in question makes an average of 500 surgeries per month.

A data collection form was used to collect personal data about the patient and about the anesthetic-surgical procedure, VNS and PHDS. Patients were invited to participate in the study as soon as they arrived in the preoperative waiting room of the surgical center, where they waited before being taken to the operating theater. After accepting, willing patients signed informed consent forms. Data collection began in the ARR after confirming that the participants were off oxygen therapy, awake and aware, and able to answer the questions. Initially, they were questioned about feeling thirsty and its intensity using the VNS with scores from 0 to 10, where 0 represented no thirst and 10 the worst possible thirst. For patients who reported feeling thirsty, their discomfort was evaluated using the PHDS. The scale was applied by asking the participant how much each attribute bothered him with 0 being 'not at all', 1 being 'a little' and 2 being 'very much'. The total score of the PHDS ranges from 0 to 14 , where the higher the score, the greater the discomfort.

Data collection was carried out by two authors of this study, members of the Research and Study Group on Thirst at the study institution, with knowledge about the topic and experience in the care of patients during the IPO. A pilot study was carried out with five participants to improve the dialogue used for data collection but no changes were considered necessary. Participants in the pilot study were not included in this study.

Data were input twice in an Excel spreadsheet and were analyzed using the Statistical Package for Social Science (SPSS) software, version 20.0. The qualitative variables (sex, surgical specialty, classification of surgical risk by the American Society of Anesthesiologists (ASA), anesthetic technique, opioid use, anticholinergic agent use, type of care, presence of thirst and spontaneous complaint of thirst) were described by frequency of the participants.
Normal distributions of the study variables were confirmed by the Shapiro-Wilk test. Numerical variables are presented as means and interquartile range: age, length of preoperative fasting of solids and liquids, intensity of thirst and PHDS score. As some data did not present a normal distribution, Spearman's $\rho$ (rho) test was used for independent samples to correlate age, length of preoperative fasting, and opioid use with intensity of thirst and discomfort. Statistical differences were considered significant when $p$-values were $<0.05$.

The study complied with the formal requirements of national and international regulatory standards for research involving human subjects and began after the participants had read and signed the informed consent form. The project was approved by a Research Ethics Committee in February 2016 (CAAE number: 51012415.3.0000.5231).

\section{RESULTS}

Table 1 shows that of the 203 participants, 182 (89.6\%) reported feeling thirsty, $63.7 \%$ of whom were female and the mean age was $41.5( \pm 15.8)$ years. Regarding the type of care, $60.9 \%$ were elective and $39.1 \%$ were urgent surgeries. The most frequent surgical specialty was gynecology and obstetrics $(31.8 \%)$, followed by orthopedics (23\%) and urology (15.9\%). The majority of participants $(52.7 \%)$ were classified as ASA II. The most used anesthetic technique was spinal anesthesia (52.7\%); $95 \%$ of the participants received opioids and $32.4 \%$ received anticholinergic agents.

Table 2 shows the participants, who reported feeling thirst spontaneously, the length of preoperative fasting for liquids and solids, and the intensity of thirst and discomfort.

The results show that of the 182 participants who reported feeling thirsty, only $22(12 \%)$ voiced it spontaneously. A long preoperative fasting time (mean of 16.2 hours) was found for liquids as well as for solids (mean of 17.3 hours).

Table 3 shows the attributes evaluated by the PHDS and the degree of discomfort. All the seven attributes used in the scale were cited by the patients. Dry mouth and the desire to drink water were the most common ( $87.3 \%$ for both), followed by dry lips $(79.1 \%)$, dry throat $(75.2 \%)$, bad taste in the mouth $(63.1 \%)$, thick saliva $(56.5 \%)$ and thick tongue feeling $(43.4 \%)$.

Table 4 shows the correlation of factors related to the intensity of thirst and degree of discomfort.

There was no statistically significant differences for the variables age, fasting time, and the use of opioids and anticholinergic agents in respect to the intensity of thirst and degree of discomfort. However, this study found a positive moderate correlation (Spearman $=0.474$ ) of the intensity of thirst with the PHDS score. 
Table 1. Characterization of the patients who reported feeling thirsty in the anesthesia recovery room according to the clinical-surgical variables

\begin{tabular}{|c|c|c|}
\hline Variable & Mean & SD \\
\hline \multirow[t]{2}{*}{ Age (years) } & 41.5 & 15.8 \\
\hline & $\mathbf{n}$ & $\%$ \\
\hline \multicolumn{3}{|l|}{ Sex } \\
\hline Female & 116 & 63.7 \\
\hline Male & 66 & 36.3 \\
\hline \multicolumn{3}{|l|}{ Surgical specialty } \\
\hline Gynecology and Obstetrics & 58 & 31.8 \\
\hline Orthopedics & 42 & 23.0 \\
\hline Urology & 29 & 15.9 \\
\hline Others & 53 & 29.3 \\
\hline \multicolumn{3}{|c|}{ Surgical risk classification (ASA)* } \\
\hline I & 81 & 44.5 \\
\hline II & 96 & 52.7 \\
\hline III & 5 & 2.8 \\
\hline \multicolumn{3}{|l|}{ Type of care } \\
\hline Elective surgery & 111 & 60.9 \\
\hline Urgent surgery & 71 & 39.1 \\
\hline \multicolumn{3}{|l|}{ Opioid use } \\
\hline Yes & 173 & 95.0 \\
\hline No & 9 & 5.0 \\
\hline \multicolumn{3}{|l|}{ Anticholinergic agent use } \\
\hline Yes & 59 & 32.4 \\
\hline No & 123 & 67.6 \\
\hline \multicolumn{3}{|l|}{ Anesthesia technique } \\
\hline Spinal anesthesia & 96 & 52.7 \\
\hline General Balanced & 46 & 25.2 \\
\hline Spinal anesthesia + General & 2 & 1.0 \\
\hline Epidural Blockage + General & 15 & 8.2 \\
\hline Others & 23 & 12.9 \\
\hline
\end{tabular}

\section{DISCUSSION}

The relevance of this study is shown by the intentional investigation of the intensity of thirst durng the IPO and to identify the attributes that cause discomfort. All the attributes evaluated by the PHDS were identified by the patients in the present research; this demonstrates that this scale is an instrument that is useful to identify discomfort related to perioperative thirst. The intensity of thirst - habitually investigated in studies on this topic - was not the only parameter evaluated; the correlation between
Table 2. Characterization of surgical patients in the Anesthesia Recovery Room regarding the intensity of thirst and resulting discomfort

\begin{tabular}{|c|c|c|}
\hline Variable & $\mathbf{n}$ & $\%$ \\
\hline \multicolumn{3}{|l|}{ Felt thirsty } \\
\hline Yes & 182 & 89.6 \\
\hline No & 21 & 10.4 \\
\hline \multicolumn{3}{|l|}{ Reported spontaneously } \\
\hline Yes & 22 & 12.0 \\
\hline \multirow[t]{2}{*}{ No } & 160 & 88.0 \\
\hline & Mean & SD \\
\hline $\begin{array}{l}\text { Preoperative fasting time for } \\
\text { liquids (hours) }\end{array}$ & 16.2 & 8.7 \\
\hline $\begin{array}{l}\text { Preoperative fasting time for } \\
\text { solids (hours) }\end{array}$ & 17.3 & 9.0 \\
\hline Intensity of thirst (points)* & 6.9 & 2.4 \\
\hline Degree of discomfort (points) ${ }^{* *}$ & 7.3 & 3.7 \\
\hline
\end{tabular}

the intensity of thirst and attributes related to the degree of discomfort, a factor that has a considerable impact on recovery after surgery, was also investigated.

Thirst can be defined as the conscious desire to drink water. ${ }^{17}$ Perception of thirst and behavior to drink water may be motivated by different factors, such as physiological aspects, individual differences, desire to stop the feeling of a dry mouth and personal characteristics related to enteroception. ${ }^{4,5,18}$

Surgical patients deal with thirst as a stressor according to their culture, knowledge, preoperative guidance, and previous experiences, among other factors. ${ }^{5}$ Their perception of thirst, as a result of hormonal and neural stimuli, as well as the perception of pain, creates a threshold that varies according to the particularity of each individual and their experience. ${ }^{5}$

The prevalence of thirst was high in this study, higher than in another study in an Anesthesia Recovery Room. ${ }^{\text {T Therefore, the }}$ magnitude of this problem is great and deserves to be studied. Some challenges need to be overcome when assessing thirst with the first one being the importance given to this symptom by the care team. At the time of anesthetic recovery, it is believed that other symptoms such as pain, nausea and hypothermia require more attention because they indicate possible complications. ${ }^{12,13}$

The prevalence of thirst in this study and the reports of patients show how this symptom can be unsettling during the IPO. Considered a multifactorial symptom, thirst can be triggered by individual, emotional and physiological factors. ${ }^{4,19}$ It is important to remember that the period in which the patient remains fasting, and the use of opioids and anticholinergic agents are associated with mechanisms that trigger thirst in surgical patients. ${ }^{15,16}$ 
Table 3. Attributes assessed by the Perioperative Thirst Discomfort Scale (PHDS) and the degree of discomfort of surgical patients in the Anesthesia Recovery Room

\begin{tabular}{lccccc}
\hline Attributes of PHDS & N & \% & None & $\begin{array}{c}\text { Degree of discomfort } \\
\text { Little } \\
\text { n }\end{array}$ & Much \\
\hline Dry mouth & & & $\mathbf{N}$ & 79 & 80 \\
\hline Dry lips & 159 & 87.3 & 38 & 78 & 66 \\
\hline Thick tongue feeling & 144 & 79.1 & 103 & 53 & 26 \\
\hline Thick saliva & 79 & 43.4 & 79 & 61 & 42 \\
\hline Dry throat & 103 & 56.5 & 45 & 72 & 65 \\
\hline Bad taste in mouth & 137 & 75.2 & 67 & 51 & 64 \\
\hline Desire to drink water & 115 & 63.1 & 23 & 55 & 104 \\
\hline
\end{tabular}

Table 4. Correlation between age and fasting time for liquids and solids with intensity of thirst and degree of discomfort according to the Perioperative Thirst Discomfort Scale (PHDS) in surgical patients in the Anesthesia Recovery Room

\begin{tabular}{lcccc}
\hline \multirow{2}{*}{ Variable } & \multicolumn{2}{c}{ Intensity of thirst } & \multicolumn{2}{c}{ Degree of discomfort } \\
& Coefficient* & p-value & Coefficient* & p-value \\
\hline Age & -0.122 & 0.101 & -0.129 & 0.083 \\
Preoperative fasting time for liquids & 0.101 & 0.174 & 0.028 & 0.704 \\
Preoperative fasting time for solids & 0.076 & 0.309 & 0.077 & 0.300 \\
Use of opioids & 0.020 & 0.793 & -0.044 & 0.553 \\
Use of anticholinergic & -0.010 & 0.987 & 0.057 & 0.447 \\
\hline
\end{tabular}

* Spearman's $\rho$ (rho) test.

Studies performed in patients in the ICU during the postoperative period of heart surgery reported that thirst was an important stressor. The patients considered thirst distressing and stressful and thus interfering in their recovery. ${ }^{20}$ This group of patients classified thirst as the most significant stressor of 50 evaluated factors. ${ }^{10}$

Preoperative fasting is one variable evaluated in this study; it is important to prevent pulmonary aspiration of the gastric contents after the loss of airway protective reflexes due to anesthetic drugs. ${ }^{21,22}$ Pulmonary aspiration is a complication feared by the surgical team which may explain the long fasting time usually practiced. However, this is not the best conduct, since prolonged fasting increases the production of gastric juice and further decreases its $\mathrm{pH}$, resulting in an increased risk of complications including pulmonary aspiration. ${ }^{22}$

The recommendation length of fasting for surgical procedures is two hours for clear liquids and six hours for solid nongreasy foods. ${ }^{21}$ In the present study, no correlation was found between the fasting time and the intensity of thirst and degree of discomfort. However, the mean fasting time was far above the recommended; about 14 hours longer for liquids and 11 hours longer for solid foods.
All participants, therefore, fasted for a minimum of eight hours, which may be one of the factors that made it difficult to compare the variables in shorter fasting times. This finding corroborates the results of a previous study in which a variation of eight to 37 hours of preoperative fasting was reported. ${ }^{1}$ Among the factors that may have contributed to the results in relation to fasting in the present study is the fact that data collection was performed in a university hospital in which many surgeries are postponed ${ }^{23}$ resulting in prolonged fasting.

The use of opioids and anticholinergic agents was also evaluated. One of the adverse effects of these drugs is thirst due to a reduced production of saliva, which results in dryness of the mouth. ${ }^{15,16}$ In this study, no significant correlation was found for the use of anticholinergic agents and opioids with the intensity of thirst and the resulting discomfort. It is suggested that other comparative investigations should be conducted with similar control and experimental groups to evaluate if there is an association between anesthetic drug use and the intensity of thirst and discomfort, as well as to investigate if there is a dose-dependent relationship.

The age of the patient is one of the individual conditions that may influence the sensation of thirst. Aging changes the 
perception of thirst ${ }^{4}$ as elderly people report less thirst in hot conditions, during exercise and after trauma and require more time to recover their fluid balance. ${ }^{24}$ Even in situations where drinking is allowed, the elderly ingest less water; this may happen due to the fear of incontinence, the inaccessibility of toilets and immobility. ${ }^{3}$ In this study, there was no statistical association between age and intensity of thirst and subsequent discomfort. Studies with a calculated sample size are necessary to understand this variable better. In this research, due to the small sample of elderly patients, it was not possible to analyze the thirst in older people.

This study found that the intensity of thirst was high. In another study in which the authors evaluated the use of ice popsicles compared to water at room temperature in the Anesthesia Recovery Room, the mean intensities of thirst were 6.7 and 6.3 for the two groups, ${ }^{25}$ similar to the findings of this research.

Of the factors that contribute to the high intensity of thirst of the surgical patient are emotional aspects including anxiety that starts in the preoperative period. Consequently, there is a decrease in salivary flow resulting in dryness of the mouth, thus contributing to the thirst. ${ }^{5}$ In addition, osmotic and volumetric imbalances inherent to the surgical procedure contribute to the patient's greater risk to develop thirst. This is therefore evidenced by intense thirst when the patient recovers from anesthesia. ${ }^{5}$

In this study, the attributes assessed by PHDS showed that a dry mouth and the desire to drink water are the most common and result in greater discomfort for the patient, corroborating the most frequent factors related to thirst reported in the literature. Individuals who experience thirst, describe dry mouth as the most aversive factor ${ }^{4}$ and this perception is one of the attributes most frequently associated with thirst. $3,18,26$

The scale assessing discomfort, PHDS, was recently created and validated and so its use has not been widely reported in the literature yet. For this reason, no research was found to corroborate the present findings, making comparative discussions difficult. However, these results are relevant because they explain the attributes that surgical patients actually experience. This perspective broadens the view regarding the measurement of thirst, going beyond intensity as the only identifying factor.

The positive relationship between the intensity of thirst and the score of discomfort evaluated by the PHDS indicated that there is a correlation between the intensity reported by the patient using the VNS and the PHDS. A review article, ${ }^{6}$ reported clinical trials related to thirst with the key physiological factors and measurements. In all the trials, there was a close association of the score obtained by scales that evaluate thirst with increases in the osmolarity and vasopressin levels, two factors related to the physiology of thirst. Thus, the VNS can somehow identify osmotic alterations of the patient and, by using the PHDS, it is possible to verify the increase in discomfort caused by thirst in surgical patients, clearly identifying the attributes that most bother them.

In view of the magnitude of thirst and the resulting discomfort, the importance of the care provided to the surgical patient by the nursing team is evident. Care integrates the essence of nursing, particularly in such a sensitive area for human beings.

Thirst is a symptom that reflects one of the individual's primary needs. ${ }^{14}$ Therefore, we are not being attentive to the patients' needs when we allow them to remain with intense discomfort during the IPO without receiving care to alleviate this symptom. Effective strategies in the management of thirst ${ }^{25,27}$ and protocols that evaluate the safety ${ }^{28}$ of these strategies are already available in the clinical practice, allowing relief of the discomfort, particularly in the ARR.

\section{CONCLUSIONS AND IMPLICATIONS IN THE CLINICAL PRACTICE}

The prevalence of thirst, its intensity and the resulting discomfort was high in patients during the IPO in the ARR. There was a positive relationship between this intensity and the PHDS score, demonstrating that the higher the intensity of thirst, the more the patient perceives the resulting discomfort. This shows how prevalent and intense this symptom is experienced, especially by surgical patients.

All the attributes related to thirst included in the PHDS were reported by patients showing that this instrument can adequately measure these attributes. Thirst needs to be evaluated by the healthcare team that works in the ARR, in order for it to be appropriately treated.

One of the limitations of this investigation was that the sample size was not calculated; if it had been, it may have been possible to elucidate any relationship between the predictor variables and the outcome. Another limitation was the small number of elderly patients, which did not allow this age group to be evaluated separately.

However, the study revealed little known data on the discomfort caused by thirst, its characteristics and the relationship with its intensity reported in a period when it is usually not even considered part of care. It is hoped that the reported data broadens reflections on the conduct during anesthetic recovery, aiming at improving the care provided to the surgical patient including the verification of thirst, and contributing to the humanization of the care of surgical patients.

\section{REFERENCES}

1. Aroni P, Nascimento LA, Fonseca LF. Assessment strategies for the management of thirst in the post-anesthetic recovery room. Acta Pau Enferm [Internet]. 2012; [cited 2018 Apr 27]; 25(4):530-6. Available from: http://www.scielo.br/scielo.php?script=sci_arttext\&pid=S0103 $21002012000400008 \& \operatorname{lng}=$ en\&nrm=iso\&tlng=en 
2. Rolls BJ, Wood RJ, Rolls ET, Lind H, Lind W, Ledingham JG. Thirst following water deprivation in humans. Am J Physiol [Internet]. 1980 Nov; [cited 2018 Apr 27]; 239(5):R476-82. Available from: https://www. ncbi.nlm.nih.gov/pubmed/7001928

3. Arai S, Stotts N, Puntillo K. Thirst in critically ill patients: from physiology to sensation. Am J Crit Care [Internet]. 2013 Jul; [cited 2018 Apr 27] 22(4):328-35. Available from: https://www.ncbi.nlm.nih.gov/pubmed/?t erm=Thirst+in+critically+ill+patients $\% 3 A+$ from+physiology+to+sensat ion.+Am+J+Crit+Care.+2013\%3B22(4)\%3A328-35

4. Stevenson RJ, Mahmut M, Rooney K. Individual differences in the interoceptive states of hunger, fullness and thirst. Appetite [Internet] 2015 Dec; [cited 2018 Apr 27]; 95:44-57. Available from: https://www. ncbi.nlm.nih.gov/pubmed/?term=Individual+differences+in+the+inter oceptive+states+of+hunger\%2C+fullness+and+thirst.+Appetite.+201 5\%3B95\%3A44-57

5. Conchon MF, Nascimento LA, Fonseca LF, Aroni P. Sede perioperatória: uma análise sob a perspectiva da Teoria de Manejo de Sintomas. Rev Esc Enferm USP [Internet]. 2015; [cited 2018 Apr 27]; 49(1):122-8. Available from: http://www.scielo.br/pdf/reeusp/v49n1/pt_0080-6234reeusp-49-01-0122.pdf

6. Arai SR, Butzlaff A, Stotts NA, Puntillo KA. Quench the thirst: lessons from clinical thirst trials. Biol Res Nurs [Internet]. 2014 Oct; [cited 2018 Apr 27]; 16(4):456-66. Available from: https://www.ncbi.nlm.nih.gov/pu $\mathrm{bmed} /$ ?term=Quench+the+thirst\%3A+lessons+from+clinical+thirst+tri als

7. Martins PR, Fonseca LF. Avaliação das dimensões da sede: revisão integrativa. Rev Eletr Enferm [Internet]. 2017; [cited 2018 Feb 15]; 19:113. Available from: http://dx.doi.org/10.5216/ree.v19.40288

8. Martins PR, Fonseca LF, Rossetto EG, Mai LD. Developing and validating the Perioperative Thirst Discomfort Scale. Rev Esc Enferm USP [Internet]. 2017 Jul; [cited 2018 Apr 27]; 51:e03240. Available from: http://www. scielo.br/scielo.php?pid=S0080-62342017000100436\&script=sci_ arttext

9. Fortunato JGS, Furtado MS, Hirabae LFA, Oliveira JA. Escalas de dor no paciente crítico: uma revisão integrativa. Rev Hosp Univ Pedro Ernesto [Internet]. 2013 Jul/Sep; [cited 2018 Apr 27]; 12(3):110-7. Available from: http://revista.hupe.uerj.br/detalhe_artigo.asp?id=426

10. Dessotte CAM, Rodrigues HF, Furuya RK, Rossi LA, Dantas RAS. Estressores percebidos por pacientes no pós-operatório imediato de cirurgia cardíaca. Rev Bras Enferm [Internet]. 2016; [cited 2018 Apr 27]; 69(4):694-703. Available from: http://www.scielo.br/pdf/reben/ v69n4/0034-7167-reben-69-04-0741.pdf

11. Silva LCJR, Silva R, Aroni P, Fonseca LF. Tenho sede! Vivência do paciente cirúrgico no período perioperatório. Rev SOBECC [Internet]. 2016; [cited 2018 Apr 27]; 21(2):75-81. Available from: https://revista. sobecc.org.br/sobecc/article/view/21

12. Pavani MM, Fonseca LF, Conchon MF. Sede do paciente cirúrgico: percepções da equipe de enfermagem nas unidades de internação. Rev Enferm UFPE On Line [Internet]. 2016 Sep; [cited 2018 Apr 27]; 10(9):3352-60. Available from: file:///C:/Users/susana/ Downloads/11416-26192-1-PB.pdf

13. Garcia ACKA, Nascimento LA, Conchon MFC, Garcia AKAG, Fonseca LF. Perspectiva do anestesiologista em relação à sede no pós-operatório imediato. Ciênc Cuid Saúde [Internet]. 2017 Jul/Sep; [cited 2018 Apr 27]; 16(3):1-7. Available from: http://www.periodicos.uem.br/ojs/index. php/CiencCuidSaude/article/view/37241/21583

14. Kolcaba KY. A theory of holistic comfort for nursing. J Adv Nurs [Internet]. 1994 Jun; [cited 2018 Apr 27]; 19(6):1178-84. Available from: https:// www.ncbi.nlm.nih.gov/pubmed/?term=14.\%09Kolcaba+KY.+A+theory +of+holistic+comfort+for+nursing.+J+Adv+Nurs

15. Guggenheimer J, Moore PA. Xerostomia: etiology, recognition and treatment. J Am Dent Assoc [Internet]. 2003 Jan; [cited 2018 Apr 27]; 134(1):61-9. Available from: https://www.ncbi.nlm.nih.gov/ pubmed/12555958
16. Ortenzi AV. Medicação pré-anestésica. In: Cangiani LM, Posso IP, Potério GMB, Nogueira CS. Tratado de Anestesiologia: SAESP. 6ª ed. São Paulo: Atheneu; 2006.

17. Leiper J. Thirst. In: Caballero B, Allen L, Prentice A, eds. Encyclopedia of human nutrition. 2nd ed. University of Aberdeen, UK: Elsevier Academic Press; 2005. p.278-86.

18. Armstrong LE, Ganio MS, Klau JF, Johnson EC, Casa DJ, Maresh CM. Novel hydration assessment techniques employing thirst and a water intake challenge in healthy men. Appl Physiol Nutr Metab [Internet]. 2012 Feb; [cited 2018 Apr 27]; 39(2):138-44. Available from: https://www.ncbi. $\mathrm{nlm}$.nih.gov/pubmed/?term=Novel+hydration+assessment+techniques +employing+thirst+and+a+water+intake+challenge+in+healthy+men

19. Dodd M, Janson S, Facione N, Faucett J, Froelicher ES, Humphreys $\mathrm{J}$, et al. Advancing the science of symptom management. J Adv Nurs [Internet]. 2001 Mar; [cited 2018 Apr 27]; 33(5):668-76. Available from: https://www.ncbi.nlm.nih.gov/pubmed/?term=19.+Dodd+M\%2C+Jan son $+\mathrm{S} \% 2 \mathrm{C}+$ Facione $+\mathrm{N} \% 2 \mathrm{C}+$ Faucett $+\mathrm{J} \% 2 \mathrm{C}+$ Froelicher $+\mathrm{ES} \% 2 \mathrm{C}+\mathrm{H}$ umphreys+J\%2C+et+al.+Advancing+the+science+of+symptom+man agement

20. Lisboa Gois FC, Maimoni Aguillar SV, Llapa Rodriguez EO. Fatores estressantes para o paciente submetido a cirurgia cardíaca. Invest Educ Enferm [Internet]. 2012; [cited 2018 Apr 27]; 30(3):312-9. Available from http://www.scielo.org.co/scielo.php?script=sci_abstract\&pid=S0120$53072012000300003 \&$ Ing =pt\&nrm=iso\&tlng=pt

21. Andrew-Romit JJ, van de Mortel TF. Ritualistic preoperative fasting: is it still occurring and what can we do about it? ACORN J Perioper Nurs Australia [Internet]. 2011; [cited 2018 Apr 27] 24(1):14-9. Available from: https://epubs.scu.edu.au/cgi/viewcontent. cgi?article $=2013 \&$ context=hahs_pubs

22. de Aguilar-Nascimento JE, Dock-Nascimento DB. Reducing preoperative fasting time: A trend based on evidence. World J Gastrointest Surg [Internet]. 2010 Mar; [cited 2018 Apr 27]; 2(3):57-60. Available from: https://www.ncbi.nlm.nih.gov/pubmed/?term=Reducin g+preoperative+fasting+time $\% 3 \mathrm{~A}+\mathrm{a}+$ trend+based+on+evidence

23. Nascimento LA, Fonseca LF, Garcia ACKA. Suspensão cirúrgica: perspectiva do residente de medicina em clínicas cirúrgicas. Rev Bras Educ Med [Internet]. 2014; [cited 2018 Apr 27]; 38(2):20512. Available from: http://www.scielo.br/scielo.php?pid=S0100 $55022014000200007 \&$ script=sci_abstract\&tIng=es

24. Kenney WL, Chiu P. Influence of age on thirst and fluid intake. Med Sci Sports Exerc [Internet]. 2001 Sep; [cited 2018 Apr 27]; 33(9):1524-32. Available from: https://www.ncbi.nlm.nih.gov/pubmed/?term=Influence +of+age+on+thirst+and+fluid+intake.+Med+Sci+Sports+Exerc.+2001 \%3B33(9)\%3A1524-32

25. Conchon MF, Fonseca LF. Efficacy of an Ice Popsicle on Thirst Management in the Immediate Postoperative Period: A Randomized Clinical Trial. J Perianesth Nurs [Internet]. 2018; [cited 2018 Apr 27] 33(2):153-61. Available from: https://www.sciencedirect.com/science/ article/pii/S1089947216302489. DOI: https://doi.org/10.1016/j. jopan.2016.03.009

26. Thornton SN. Thirst and hydration: physiology and consequences of dysfunction. Physiol Behav [Internet]. 2010 Apr; [cited 2018 Apr 27] 100(1):15-21. Available from: https://www.ncbi.nlm.nih.gov/pubmed/?t erm $=$ Thirst+and+hydration $\% 3 \mathrm{~A}+$ physiology+and+consequences+of + dysfunction.+Physiol+Behav.+2010\%3B100(1)\%3A15-21

27. Garcia AKA, Fonseca LF, Aroni P, Galvão CM. Estratégias para o alívio da sede: revisão integrativa da literatura. Rev Bras Enferm [Internet] 2016; [cited 2018 Apr 27]; 69(6):1215-22. Available from: http://www. scielo.br/scielo. php?pid=S0034-71672016000601215\&script=sci_ abstract\&tIng=pt

28. Nascimento LA, Fonseca LF, Rosseto EG, Santos CB. Development of a safety protocol for management thirst in the immediate postoperative period. Rev Esc Enferm USP [Internet]. 2014 Oct; [cited 2018 Apr 27]; 48(5):834-43. Available from: http://www.scielo.br/scielo. php?script=sci_arttext\&pid=S0080-62342014000500834 